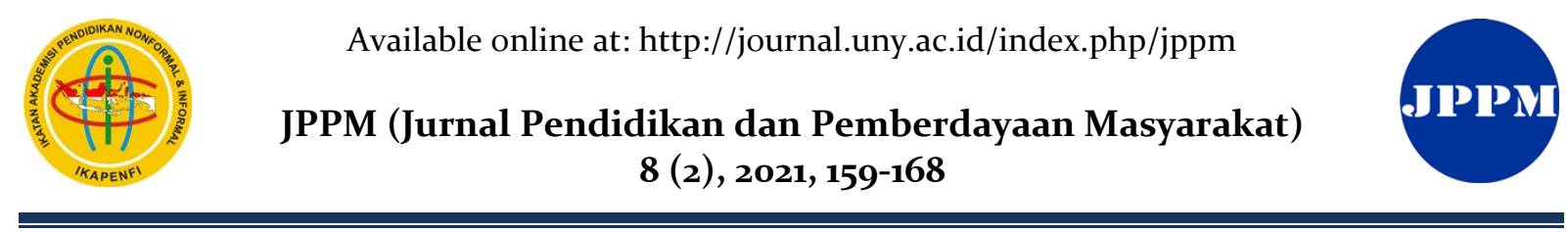

\title{
Virtual Learning in English Course at LKP Mahesa Institute Kampung Inggris Pare Kediri
}

\author{
Wiwin Yulianingsih ${ }^{\text {* }}$, Soedjarwo², Rivo Nugroho³, Maria Veronica Roesminingsih", \\ Monica Widyaswari 5 \\ ${ }^{12345}$ Non-Formal Education Department, Universitas Negeri Surabaya \\ Lidah Wetan St., Surabaya 60213, Indonesia \\ * Author Correspondence. Email: wiwinyulianingsih@unesa.ac.id, Tel.: +6281330551762 \\ Received: 26 April 2021; Revised: 10 September 2021; Accepted: 04 October 2021
}

\begin{abstract}
This study aims at describing virtual learning in English courses at LKP Mahesa Institute Kampung English Pare Kediri. This study employs a quantitative research design. The population and sample included 100 people with the ones taking courses at LKP Mahesa Institute Kampung Inggris Pare Kediri as the research subjects. The sampling technique used in this research is total sampling. The data were analysed using descriptive statistics in the form of percentages. The overall research results show that virtual learning with the approach of creating and sharing interactive content in English courses is categorized good with a percentage of $78.42 \%$. These results are supported by the suitability of the results in each of the sub-variables, namely teaching quality, teaching level, incentive, and time. In this case, virtual learning with the approach of creating and sharing interactive content in English courses is quite effective. Therefore, this learning system is expected to be one of the new approaches that can be applied in English courses, especially during the Covid-19 pandemic which applies distance learning.
\end{abstract}

Keywords: virtual learning, courses, distance learning

How to Cite: Yulianingsih, W., dkk. (2021). Virtual Learning in English Course at LKP Mahesa Institute Kampung Inggris Pare Kediri.JPPM (Jurnal Pendidikan dan Pemberdayaan Masyarakat), 8(2), 159-168. doi: 10.21831/jppm.v8i2.40389

\section{Introduction}

A language course centre has been established in one of the villages in Indonesia, focusing on English language education, known as Kampung Inggris Pare Kediri. Kampung Inggris, where some English course institutions are located, is in Tulungrejo Village, Pare, Kediri, East Java. The existence of more than one hundred English course institutions has been supporting to create an environment for students to improve their English in daily basis. These institutions have provided learning facilities and designs which are suitable for those who need to experience the English course learning. According to (Ruhamak and Rahayu 2016), Pare is one of the sub-districts in Kediri Regency, East Java which has offered various types of language course institutions. In this case, especially in Tulungrejo Village, out of various types of language courses, the English courses are very dominating and are considered as the most potential ones. These English courses generally take short period to support students to master the language. In other words, the courses can work effectively. On top all of these, English courses are now considered increasingly a necessity for students, college students, and even workers. Given that it is very meaningful, the article 26 in the Law no. 20 of 2003 concerning the National Education System states that courses and trainings are held for those who need knowledge, expertise, life skills, and attitudes to develop themselves, 


\section{JPPM (Jurnal Pendidikan dan Pemberdayaan Masyarakat), 8 (2), 2021 - 160 \\ Wiwin Yulianingsih, Soedjarwo, Rivo Nugroho, Maria Veronica Roesminingsih, Monica Widyaswari}

their professions, work, independent businesses, and/or continue their education to a higher level (Sisdiknas: 2003). Therefore, courses are considered very productive investment.

Since early 2020, the whole world has experienced a non-natural disaster caused by a type of Corona virus or severe acute syndrome coronavirus 2 (SARS-CoV-2) or better known as Covid-19 (Lai et al. 2020). This disaster has brought about extraordinary impacts on some aspects of life, including health, economy, social, worship and so on. In terms of public health, because of being exposed to Covid-19, many people have done self-isolation as required (Mellynia et al. 2020). In addition, the number of deaths due to Covid-19 has been increasing every day, so the government has made policies by limiting people's activities outside in order to prevent the spread of the virus. These policies have resulted in the limitation on people's interaction in most of public services because the fact says that the spread of Covid-19 can be mostly through the interaction (Aryani 2020; Cahyani 2021; Masruroh and Munastiwi 2020). The Covid-19 pandemic has also had an impact on several sectors of Kampung Inggris Pare Kediri, including camps (inns), boarding houses, and other informal sector workers. In fact, it also has a significant impact on course institutions ranging from managers, tutor teams, course participants, to administrative staff. Added to this, the implementation of education which is usually conducted face-to-face has now been shifted to distance learning (El Refae, Kaba, and Eleter 2021). The implementation of distance learning system is also supported by Nadiem Anwar Makarim, B.A., M.B.A. as the Minister of Education and Culture. For that, he has stipulated and issued the Circular Letter Number 4 of 2020 concerning the Implementation of Education Policies in the Emergency Period for the Spread of Covid-19. The existence of this policy requires all formal and non-formal educational institutions to comply with the applicable circular, including training institutions and courses that are the domain of the Out-of-school Education/Nonformal Education (PLS/PNF) pathway. To summary, the Covid-19 pandemic has greatly disrupted activities and has also changed the pattern of human life. For instance, Pare English course institutions are currently using virtual learning alternatives to carry out their learning activities.

Kampung Inggris has been known to be a reference for gaining knowledge and improving skills in English. This is because English mastery is indeed influential for the success of the learning participants to access and obtain information related to English considering that in this increasingly modern era, the majority of information uses English. Therefore, the ability to utilize English must also be honed in everyday life due to its many advantages. Moreover, the English mastery is one of the most decisive skills in obtaining employment (Joy and Shaby 2021).

LKP Mahesa Institute is one of the institutions concerning on the non-formal education in Kampung Inggris. Based on the results of the preliminary study, LKP Mahesa Institute belongs to the 10 largest and best course institution in Kampung Inggris. In fact, the institution has the highest number of participants placing the third position and has been accredited by the National Accreditation Board for Early Childhood Education and Non-formal Education (BAN PNF). LKP Mahesa Institute has already got a good track record and reputation. This is indicated by the increase in the number of course participants every year as well as its good and very representative infrastructure. The increase in the number of participants in the English course is in line with the people's need for mastery of English. However, during the pandemic, the 
JPPM (Jurnal Pendidikan dan Pemberdayaan Masyarakat), 8 (2), 2021 - 161

Wiwin Yulianingsih, Soedjarwo, Rivo Nugroho, Maria Veronica Roesminingsih, Monica Widyaswari

number of course participants has declined. Consequently, the LKP Mahesa Institute managers have adapted to the application of learning in new ways through online media, so as not to be left behind by competing institutions.

In the midst of the current Covid-19 pandemic, LKP Mahesa Institute as an educational institution is required to remain consistent in providing excellent service for the course participants. For that, the LKP Mahesa Institute is currently implementing virtual-based learning. This proves that virtual or online learning is not only applicable for formal education, but also for non-formal education. Virtual learning refers to the learning process which occurs in virtual classrooms situated in cyberspace through the internet (Pannen 1999). The application of virtual learning is intended to overcome the problem of the space and time separation between learners and teachers through computer media (Sudirman and Sulaeman 2020). Learners can obtain learning materials that have been designed in learning packages available on the internet site (Basilaia and Kvavadze 2020).

In this case, the online learning system is designed to support learning programs at LKP Mahesa Institute, both weekly (speaking, grammar, pronunciation, and vocabulary) and monthly classes (speaking, grammar, TOEFL Online test simulation, and TOEFL). The virtual learning system built to support LKP Mahesa Institute uses learning platforms such as google meet and zoom. This virtual learning provides convenience in distance learning that can be supported with the sustenance of the internet and several other media such as school television, zoom, slack, google meet, and the edupage platforms. This learning system is expected to be able to facilitate course participants develop themselves or improve their English language skills. The benefits of these media usage include the feasibility to facilitate various learning styles and attract the attention of students, and to make it easier for students to grasp the learning materials.

In order to support the virtual learning system, an innovative learning approach has been applied at LKP Mahesa Institute, namely creating and sharing interactive content. This approach is a breakthrough in virtual learning designed to encourage the involvement of English course participants. The approach of creating and sharing interactive content is one of the efforts to improve the English language skills of course participants and create the best learning experience through interactive images and videos in order to reach course participants in various parts of Indonesia. The use of the creating and sharing interactive content approach is more effective during distance learning, especially during the Covid-19 pandemic. In this case, in learning English, more innovative audio and visuals are needed to attract prospective students (Liu et al. 2018). Thus, the learning outcomes of course participants can be improved according to the learning objectives. To summary the explanation above, the purpose of this study is to describe virtual learning in English courses at LKP Mahesa Institute Kampung Inggris Pare Kediri.

\section{Method}

This study uses a quantitative approach with descriptive statistical data analysis techniques. As it is known, the descriptive research intends to describe in a structured manner related to the existing reality of a particular population as well as to provide answers to a problem and/or obtain in-depth information related to phenomena by using a quantitative approach research method (Yusuf 2016). This study describes virtual 


\section{JPPM (Jurnal Pendidikan dan Pemberdayaan Masyarakat), 8 (2), 2021 - 162 \\ Wiwin Yulianingsih, Soedjarwo, Rivo Nugroho, Maria Veronica Roesminingsih, Monica Widyaswari}

learning in the English course at LKP Mahesa Institute Kampung Inggris Pare Kediri. There are two sources of data in this study, namely primary data and secondary data. The primary data were obtained from the distribution of questionnaires to respondents through the google form platform. Meanwhile, the secondary data were in the form of documents from LKP Mahesa Institute Kampung Inggris Pare Kediri. The research population consists of 100 course participants studying at LKP Mahesa Institute. Those participants spread over five course programs including TOEFL, speaking, grammar, pronunciation, and vocabulary. Each class program contains 20 course participants. The total sampling is used as the sampling technique in this research, which is a sampling technique where the number of samples is the same as the number of population (Sugiyono 2017). Then, the Likert scale is used as the research instrument to obtain accurate data results because the alternative answers for each item have a value level from very positive to very negative or vice versa. Furthermore, this Likert scale is suitable to measure the opinions, perceptions, and attitudes of a person or group of people about certain social phenomena (Sinaga, Matondang, and Sitompul 2019).

Table 1. Scoring of Alternative Answers

\begin{tabular}{ccc}
\hline Alternative Answer & Code & $\begin{array}{c}\text { Scoring } \\
\text { Scale }\end{array}$ \\
\hline Never & SL & 5 \\
Rarely & SR & 4 \\
Sometimes & KD & 3 \\
Often & JR & $\mathbf{2}$ \\
Always & TP & $\mathbf{1}$ \\
\hline
\end{tabular}

This study uses a closed questionnaire in which alternative answers have been provided so that respondents simply put a checklist on the alternative answers which are already available in the questionnaire via the google form platform as a poll of respondents related to the situation being studied. This research instrument was developed from the indicators on the sub-variables. The virtual learning variable is based on several sub-variables including: teaching quality, teaching level, incentive, and time (Santrock 2010). The descriptive statics of SPSS 22.0 is used for analysing the obtained data. It is used to examine the variables in the research, namely virtual learning in the English Course at LKP Mahesa Institute Kampung Inggris Pare Kediri. The answers from the respondents were then analysed using the following percentage formula.

Description:

$$
\mathrm{P}=\frac{f}{N} \times 100 \%
$$

f : frequency

$\mathrm{N}$ : total number of respondents

$\mathrm{P}$ : percentage number

\section{Result and Discussion}

Virtual learning in the English Course at LKP Mahesa Institute Kampung Inggris Pare Kediri is categorized good with a percentage result of $78.42 \%$. This is supported by 
JPPM (Jurnal Pendidikan dan Pemberdayaan Masyarakat), 8 (2), 2021 - 163

Wiwin Yulianingsih, Soedjarwo, Rivo Nugroho, Maria Veronica Roesminingsih, Monica Widyaswari

the relationship between the results of each sub-variable which is used as an indicator as follows:

\section{a. Teaching Quality}

The results of the study on the teaching quality sub-variable indicate the good category with a percentage of $79.43 \%$. This is supported by the distribution table for the percentage of answers to the teaching quality sub variable.

Table 2. Percentage of Answers for Teaching Quality Sub-Variable

\begin{tabular}{ccc}
\hline Alternative Answer & F & Percentage \\
\hline Never & o & o\% \\
Rarely & 8 & $\mathbf{1 , 1 4} \%$ \\
Sometimes & 149 & $\mathbf{2 1 , 2 9} \%$ \\
Often & 398 & $56,86 \%$ \\
Always & 145 & $\mathbf{2 0 , 7 1} \%$ \\
\hline Total & $\mathbf{7 0 0}$ & $\mathbf{1 0 0} \%$ \\
\hline
\end{tabular}

Based on the information in the table 2, it is known that most of the course participants as learners chose "often" with a percentage of $56.86 \%$. The quality of course teaching is a measure that shows how high the quality of tutor interaction with learners is in the learning process in order to achieve certain learning goals. The teaching quality in courses is determined by the input, approach/method, atmosphere, and ability to carry out the management of the learning process (Pavlina, Zorica, and Pongrac 2011; Zerihun and Beishuizen 2012). Based on the explanation, it can be interpreted that the teaching quality is determined by the application of learning approaches or methods. In the application of certain learning approaches or methods, good collaboration is needed between tutors as facilitators and also course participants as the language learners.

In this study, it is stated that tutors play a role in helping to achieve teaching goals, determine and implement management of teaching materials and teaching tools provided to the learners, and regulate evaluation or assessment strategies given to learners. The results of this study are in accordance with the position of the tutors or facilitators who are considered to play a major role in the teaching process. Competent tutors are those who are responsible for educating and accommodating the needs of learners, as well as being able to create good interactions with learners. This is done in order to achieve the quality of teaching as stated in the learning objectives (Makopoulou 2018); (Young and Papinczak 2013).

\section{b. Teaching Level}

The results of the study on the teaching level sub-variable indicate the good category with a percentage of $79.47 \%$. This is supported by the distribution table for the percentage of answers to the teaching level sub-variable.

Table 3. Percentage of Answers to Teaching Level Sub-Variable

\begin{tabular}{ccc}
\hline Alternative Answer & F & Percentage \\
\hline Never & 0 & $0 \%$ \\
Rarely & 3 & $0,33 \%$ \\
Sometimes & 223 & $24,78 \%$ \\
Often & 469 & $52,11 \%$ \\
Always & $\mathbf{2 0 5}$ & $\mathbf{2 2 , 7 8 \%}$ \\
\hline Total & $\mathbf{9 0 0}$ & $\mathbf{1 0 0} \%$ \\
\hline
\end{tabular}


JPPM (Jurnal Pendidikan dan Pemberdayaan Masyarakat), 8 (2), 2021 - 164

Wiwin Yulianingsih, Soedjarwo, Rivo Nugroho, Maria Veronica Roesminingsih, Monica Widyaswari

Based on the information in the table 3, it can be seen that most of the course participants as language learners chose "often" with a percentage of $5 \mathbf{2 . 1 1} \%$. The level of tutoring at LKP Mahesa Institute Kampung Inggris Pare Kediri is able to ensure that students are ready to learn new materials or advance to a higher level of understanding of the materials. This stance is related to learners' readiness to receive additional knowledge and skills (Zerihun and Beishuizen 2012).

In this study, it was stated that tutors play an important role in helping to see the readiness of course participants in understanding the material taught at each meeting, both physically and psychologically. The results of this study are in accordance with the creation of effective learning conditions. Readiness to learn that must be considered by tutors includes preparing the course participants, preparing modules and learning resources as well as the media used. In this regard, tutors are expected to be able to build a good bonding to the learners in order to understand the conditions experienced. In this case, tutors need to observe (1) the physical, mental, and emotional conditions of learners; (2) the needs, motives, and goals of the learning community; and (3) other skills and knowledge that have been learned (DeMonte 2013; Yıldırım and Akamca 2017).

Readiness to learn resulting from a good level of teaching can certainly create learning expectations for the learners. The learners certainly have got some expectations after participating in the learning activities. Those expectations include new knowledge, good learning experience, and increased skills to be applied in their real life. By having these expectations, learners will be encouraged and motivated to perform well in learning (Rahmat Pramudia et al. 2017; Waluyo and Desamawati, 2015).

\section{c. Incentive}

The results of the research on the incentive sub-variable portray the good category with a percentage of $77.67 \%$. This is supported by the distribution table for the percentage of answers to the incentive sub-variable.

Table 4. Percentage of Answers to Incentive Sub-Variable

\begin{tabular}{ccc}
\hline Alternative Answer & F & Percentage \\
\hline Never & o & o\% \\
Rarely & 3 & $1 \%$ \\
Sometimes & 87 & $29 \%$ \\
Often & 152 & $50,67 \%$ \\
Always & 58 & $19,33 \%$ \\
\hline Total & $\mathbf{3 0 0}$ & $\mathbf{1 0 0} \%$ \\
\hline
\end{tabular}

Based on the information in the table 4, it is known that most of the course participants as learners chose "often" with a percentage of $50.67 \%$. The incentive is the extent to which tutors ensure that learners are motivated to accept the materials and carry out teaching assignments from the materials being presented. This incentive can be reviewed through tutor activities in providing motivation to learners.

In this study, it was stated that tutors at LKP Mahesa Institute Kampung Inggris Pare Kediri applied incentives to virtual learning by providing motivation to the learners, explaining concretely to learners at the end of teaching, and providing rewards for the achievements of the learners. The results of the study are as explanations which emphasize that the encouragement of course participants to learn as a result of the application of certain learning approaches or methods can help achieve learning 
JPPM (Jurnal Pendidikan dan Pemberdayaan Masyarakat), 8 (2), 2021 - 165

Wiwin Yulianingsih, Soedjarwo, Rivo Nugroho, Maria Veronica Roesminingsih, Monica Widyaswari

objectives more optimally. The encouragement or motivation of learners can come from within themselves or from outside themselves (Duffy and Azevedo 2015).

\section{d. Time}

The results of the study on the time sub-variable indicate good category with a percentage of $77.1 \%$. This is supported by the distribution table for the percentage of answers to the time sub-variable.

\begin{tabular}{ccc} 
Table 5. Percentage of Answers to Time Sub-Variable \\
\cline { 2 - 3 } Alternative Answer & F & Percentage \\
\hline Never & o & 0\% \\
Rarely & 4 & $\mathbf{2} \%$ \\
Sometimes & 60 & $30 \%$ \\
Often & 97 & $48,5 \%$ \\
Always & 39 & $19,5 \%$ \\
\hline Total & $\mathbf{2 0 0}$ & $\mathbf{1 0 0} \%$ \\
\hline
\end{tabular}

Based on the table 5 , it can be concluded that most of the course participants as learners chose "often" with a percentage of $48.5 \%$. This is evidenced by the answers of the participants who chose "often". The time is the extent to which students are given sufficient time to study the materials being taught. Learning can be said to be effective if learners can complete learning process in accordance with the specified time allocation. In this case, the English tutors pay great attention to aspects related to time, including preparing for the beginning of learning, taking into account the time for delivering the materials, taking into account the discussion time as the main point in the approach to creating and sharing interactive content, developing the materials that have been studied, and closing learning activities. The results of this study are related to the results of research (Grave 2011) that the allocation of learning time is considered very important to be taken into account by tutors. This is based on the time allocation that can affect the achievement of learning outcomes obtained by the learners.

Overall, the results of this study state that virtual learning collaborated by the approach of creating and sharing interactive content is a form of distance learning that can be applied, especially in English courses. The virtual learning refers to the learning process that occurs in virtual classrooms located in cyberspace through the internet (Pannen 1999). The application of virtual learning is intended to overcome the problem of the separation of space and time between students and teachers through computer media. By implementing virtual learning, learners studying in courses can study learning materials on their own or if needed, they can ask for help in the form of computerfacilitated interactions, such as computer-based learning (CAL) or interactive web pages, teacher-assisted learning or tutors synchronously (at the same points in time) and asynchronously (at different points in time). The assessment of the learning is also carried out remotely via a computer and openly. Through the implementation of an open assessment system, learners can take an assessment at any time as long as they are ready to be assessed (Ruggieri, Boca, and Garro 2013);(Simões and de Moraes 2012).

The concept of virtual learning is in accordance with Ivan Illich's view as one of the leaders in non-formal education that learning is not confined by space and time. Learning can be done in many places and at any time. At a time when information technology was not as sophisticated as it is today, Ivan Illich has been thinking about 
JPPM (Jurnal Pendidikan dan Pemberdayaan Masyarakat), 8 (2), 2021 - 166

Wiwin Yulianingsih, Soedjarwo, Rivo Nugroho, Maria Veronica Roesminingsih, Monica Widyaswari

the learning web (learning network). In this case Ivan Illich also emphasized that knowledge must be used to solve problems and add value to life. Whatever the busyness of the individual will always need to learn at any time, throughout his life. One of them is improving and developing English language skills (Sarmadi et al., 2020); (Serpa, Santos, and Ferreira, 2020).

\section{Conclusion}

Based on the results of the study, it can be concluded that overall virtual learning systems collaborated with the approach of creating and sharing interactive content in English courses indicate good results with a percentage of $78.42 \%$. These results are supported by the suitability of the results for each sub-variable, namely the sub-variables of teaching quality, teaching level, incentive, and time. The teaching quality includes tutors playing an important role in helping to achieve teaching goals, determining and implementing the management of teaching materials and teaching tools provided to the learners, as well as managing evaluation/assessment strategies given to the learners. The teaching level is marked by the role of the tutors in helping to see the readiness of course participants in understanding the materials taught at each meeting, both physically and psychologically.

The incentive is carried out by providing motivation to the learners, explaining concretely to the learners at the end of teaching, and providing rewards for the achievements of learning residents. Meanwhile, the time is marked by the tutors' steps in preparing for the beginning of the lesson, taking into account the time for delivering the materials, taking into account the discussion time, developing the materials that have been studied, and closing the lessons. The approach of creating and sharing interactive content is one of the efforts to improve the English language skills of course participants and create the best learning experience through interactive images and videos in order to reach course participants in various parts of Indonesia. The use of the creating and sharing interactive content approach is more effective during distance learning, especially during the Covid-19 pandemic. In this case, in learning English, more innovative audio and visuals are needed to attract prospective students. Virtual learning with the approach of creating and sharing interactive content is quite effective, and it is hoped that it can be one of the new approaches that can be applied in learning English courses, especially during the Covid-19 pandemic as it is currently implementing distance learning.

\section{References}

Aryani, Eka. 2020. "Communication of Parents and Early Childhood to Build Confidence in The Pandemic Covid-19." JPPM (Jurnal Pendidikan Dan Pemberdayaan Masyarakat) 8(1):9.

Basilaia, Giorgi, and David Kvavadze. 2020. "Transition to Online Education in Schools during a SARS-CoV-2 Coronavirus (COVID-19) Pandemic in Georgia." Pedagogical Research 5(4). doi: $10.29333 / \mathrm{pr} / 7937$.

Cahyani, Arini Dwi. 2021. "Sinergi Antara Orang Tua Dan Pendidik Dalam Pendampingan Belajar Anak Selama Pandemi Covid-19." Obsesi : Jurnal Pendidikan Anak Usia Dini 6(2). doi: 10.31004/obsesi.v6i1.1130.

Duffy, Melissa C., and Roger Azevedo. 2015. "Motivation Matters: Interactions between Achievement Goals and Agent Scaffolding for Self-Regulated Learning within an 
JPPM (Jurnal Pendidikan dan Pemberdayaan Masyarakat), 8 (2), 2021 - 167

Wiwin Yulianingsih, Soedjarwo, Rivo Nugroho, Maria Veronica Roesminingsih, Monica Widyaswari

Intelligent Tutoring System.” Computers in Human Behavior 52:338-48. doi: 10.1016/j.chb.2015.05.041.

Grave, Barbara S. 2011. "The Effect of Student Time Allocation on Academic Achievement." Education Economics 19(3):291-310. doi: 10.1080/o9645292.2011.585794.

Joy, J. John Love, and D. Shaby. 2021. "Task-Based Language Teaching: An Approach To Implement Language Skills." European Journal of Molecular \& Clinical Medicine 7(11):732332.

Lai, Chih-Cheng, Tzu-Ping Shih, Wen-Chien Ko, Hung-Jen Tang, and Po-Ren Hsueh. 2020. "Severe Acute Respiratory Syndrome Coronavirus 2 (SARS-CoV-2) and Coronavirus Disease-2019 (COVID-19): The Epidemic and the Challenges." International Journal of Antimicrobial Agents 55(3):105924. doi: 10.1016/j.ijantimicag.2020.105924.

Liu, Can, Ben Bengler, Danilo Di Cuia, Katie Seaborn, Giovanna Nunes Vilaza, Sarah Gallacher, Licia Capra, and Yvonne Rogers. 2018. "Pinsight: A Novel Way of Creating and Sharing Digital Content through'Things' in the Wild." Pp. 1169-81 in Proceedings of the 2018 Designing Interactive Systems Conference.

Makopoulou, Kyriaki. 2018. "An Investigation into the Complex Process of Facilitating Effective Professional Learning: CPD Tutors' Practices under the Microscope.” Physical Education and Sport Pedagogy 23(3):250-66. doi: 10.1080/17408989.2017.1406463.

Masruroh, Lely, and Erni Munastiwi. 2020. "Portrait Analysis of Early Childhood Education in Cities and Villages: The COVID-19 Pandemic Era." 9.

Mellynia, Rizki, Anita Trisiana, Nike Nur Viyani, Fidia Safitri, Nita Tri Handayani, and Ika Nisatul Sholehah. 2020. "Bersatu Melawan Covid 19 Dengan Hidup Sehat dalam Perspektif Pendidikan Kewarganegaraan.” Jurnal Global Citizen: Jurnal Ilmiah Kajian Pendidikan Kewarganegaraan 9(1):24-38. doi: 10.33061/jgz.v9i1.3882.

Pannen, Paulina. 1999. "Pengertian Sistem Pendidikan Terbuka Dan Jarak Jauh.” Dalam Tian Belawati, Dkk.(Ed.), Pendidikan Terbuka Dan Jarak Jauh. Jakarta: Universitas Terbuka. Hal 11-29.

Pavlina, Krešimir, Mihaela Banek Zorica, and Ana Pongrac. 2011. "Student Perception of Teaching Quality in Higher Education.” P. 5 in Procedia Social and Behavioral Sciences.

Rahmat Pramudia, Joni, Sardin Sardin, Nike Kamarubiani, and Muhammad Irfan Hilmi. 2017. "Model Management Activity Community Learning Center (Clc) Based on Local Wisdom to Improve Quality of Nonformal Education Service." 88(Nfe 2016):38-41. doi: 10.2991/nfe16.2017.10.

El Refae, Ghaleb Ghaleb A., Abdoulaye Kaba, and Shorouq Eletter. 2021. "The Impact of Demographic Characteristics on Academic Performance: Face-to-Face Learning Versus Distance Learning Implemented to Prevent the Spread of COVID-19." The International Review of Research in Open and Distributed Learning 22(1):91-110. doi: 10.19173/irrodl.v22i1.5031.

Ruggieri, Stefano, Stefano Boca, and Maria Garro. 2013. "Leadership Styles in Synchronous and Asynchronous Virtual Learning Environments.” Turkish Online Journal of Educational Technology-TOJET 12(4):96-102.

Ruhamak, M. Dian, and Budi Rahayu. 2016. "Pengaruh Word of Mouth Terhadap Purchase Intention Melalui Brand Image Pada Lembaga Kursus Bahasa Inggris Dynamic English Course Pare." EKONIKA Jurnal Ekonomi Universitas Kadiri 1(2).

Santrock, J. W. 2010. Psikologi Pendidikan. 2nd Ed. Jakarta: Kencana.

Sarmadi, Mohammad Reza, Azadeh Zare, Masoumeh Samadi, and Mehran Farajollahi. 2020. "Examining the Issues and Dimensions of Learning Webs in Ivan Ilyich's View." Journal of Educational Scinces 27(2):119-38.

Serpa, Sandro, Ana Isabel Santos, and Carlos Miguel Ferreira. 2020. "Contributions of Ivan Illich to Education in a Digital Society." Academic Journal of Interdisciplinary Studies 9(2):23. doi: 10.36941/ajis-2020-0019. 
JPPM (Jurnal Pendidikan dan Pemberdayaan Masyarakat), 8 (2), 2021 - 168

Wiwin Yulianingsih, Soedjarwo, Rivo Nugroho, Maria Veronica Roesminingsih,

Monica Widyaswari

Simões, Aliana Pereira, and Anamaria de Moraes. 2012. "The Ergonomic Evaluation of a Virtual Learning Environment Usability." Work 41(Supplement 1):1140-44. doi: 10.3233/WOR2012-0293-1140.

Sinaga, Enny Keristiana, Zulkifli Matondang, and Harun Sitompul. 2019. Statistika: Teori Dan Aplikasi Pendidikan. Yayasan Kita Menulis.

Sisdiknas. 2003. Undang-Undang Republik Indonesia Nomor 20 Tahun 2003 Tentang Sistem Pendidikan Nasional. Departemen Pendidikan Nasional.

Sudirman, Sudirman, and Ibnu Sulaeman. 2020. "Clustering Data Mining Algoritma K-Means Dalam Pengolahan Nilai Pat Pada Mata Pelajaran Bahasa Inggris, Bahasa Indonesia Dan Matematika Dengan Pembelajaran Virtual Learning." Jurnal SIGMA 10(4):181-88.

Sugiyono. 2017. Metode Penelitian Pendidikan: Pendekatan Kuantitatif, Kualitatif, RED. Cetakan Ke-25. Bandung: CV Alfabeta.

Waluyo, Yoga Tri, and Liliek Desamawati. 2015. "Peran Tutor dalam Meningkatkan Motivasi Belajar Peserta Didik melalui Pendekatan Andragogi di Rutan Banjarnegara." NFECE 4(1).

Young, Louise, and Tracey Papinczak. 2013. "Strategies for Sustaining Quality in PBL Facilitation for Large Student Cohorts." Advances in Health Sciences Education 18(4):825-33. doi: 10.1007/s10459-012-9387-7.

Yusuf, A. Muri. 2016. Metode Penelitian Kuantitatif, Kualitatif \& Penelitian Gabungan. Prenada Media.

Zerihun, Zenawi, and Jos Beishuizen. 2012. "Student Learning Experience as Indicator of Teaching Quality.” Educ Asse Eval Acc 13. 